Received 20.11.2013

Reviewed 17.02.2014

Accepted 08.05.2014

A - study design

B - data collection

C - statistical analysis

D - data interpretation

$\mathbf{E}$ - manuscript preparation

$\mathbf{F}$ - literature search

\section{Assessment of limnigraph data usefulness for determining the hypothetical flood waves with the Cracow method}

\author{
Wiesław GĄDEK ${ }^{\text {ABCDEF }}$
}

Cracow University of Technology, Environment Engineering Department, Institute of Water Engineering and Water Management, ul. Warszawska 24, 31-155 Kraków, Poland; tel. +48 12 628-28-54, e-mail: Wieslaw.Gadek@iigw.pl

For citation: Gądek W. 2014. Assessment of limnigraph data usefulness for determining the hypothetical flood waves with the Cracow method. Journal of Water and Land Development. No. 21 p. 71-78

\begin{abstract}
In our country the data related to the flow volume in the watercourses is recorded in three database systems: water-gauge, limnigraph and telemetric (digital) one. In each of those systems the flow value is presented in a different way. The aim of this publication is to present how the non-compliance of the meaning and substantive difference of water-gauge data and limnigraph data influences on the example of 7 hypothetical floods determined by the Cracow method. Cracow method was initially known as Cracow Technical University Method. The received results show that the limnigraph data does not effect significantly the parameters of the hypothetical floods. In absence of the data from the telemetric system, such analysis has not be done.
\end{abstract}

Key words: hypothetical flood, limnigraph data, the Cracow method, water-gauge data

\section{INTRODUCTION}

The aim of this article is to evaluate the influence of data recorded in the limnigraph system on the course of hypothetical hydrograph determined with the Cracow method [GADEEK 2010; 2012a]. The data recorded in the limnigraph system is the essential part of the database information on the course during the flow volume - the flow hydrograph.

The hypothetical flood means the theoretical flow hydrograph which presents typical flood wave course that may occur under certain conditions on a chosen place for set value of the peak flow.

In our country (Poland) there are several methods enabling determination of the hypothetical flood course among the others while using the equations of: Reitz-Kreps method [KICIŃSKI 1965; CIEPIELOWSKI DĄBKOWSKI 2006], BAPTIST and MiCHEL method [1990], STRUPCZEWSKI method [1964] or MCENROE method [1992]. Those equations parameters are mostly determined based on the biggest registered flood. The attempts are being taken in order to use the hy- drological models for determining this type of floods [WAŁEcGA 2013]. It is an initial stage and it is difficult to take the explicit view as for the practical usage of this approach. The most frequently for this purpose, however, there are used the methods developed at the Warsaw University of Technology [CBSiPWM 1971] and the Cracow [GADEK 2010; 2012a]. The both methods use the unified course of the single wave (UHG) while determining the hypothetical flood.

Application of the design floods is big and is increasing from year to year. The universal character of the data presented in such way causes that it is used for different types of the engineering projects [LINSLEY et al. 1975; PILGRIM 2001]. One may try to state that it replaces effectively the dependable and control flows in the designing process. At the present moment the data has the application mainly in the widely understood flood risk [APEL et al. 2006; VRIJLING et al. 1998]. It is used from estimating the area risk [BÜCHELE et al. 2006; ERNST et al. 2010], through estimating the damages in life and property [JONKMAN et al. 2008]. 
Design flood waves, on the assumption, dominate over the specific flows. It is because they not only determine the level of the design flow but also they define the wave volume as well as the time in which the maximum design flow will appear. It makes the hydrologists use the different methods that are mainly connected with modelling under different statistical and dynamical assumptions for natural and urban areas [Boughton, Droop 2003; SARMA et al. 1973; WANG et al. 2006]. These actions are not done directly; they only indicate the design flood waves indirectly. Therefore, they require good standardised specification which is not available in our country [WAŁĘGA 2013]. For the control basins, it is necessary to use the methods enabling to conduct this process as simple as possible in order to obtain the most reliable parameters describing the design flood. The most important elements while determining the course and parameters of the design flood, regardless of the method accepted, are the input details i.e. hydrological data connected with the flow course in time.

Observations at the water-gauge stations are divided into so-called: periodical and continuous observations [BYCZKOWSKI 1996]. Periodical observations, to which we include ordinary and extraordinary observations, use as the basis the reading from the staff-gauge. The ordinary observations are done mostly twice a day at 6.00 and 18.00 UCT and depending on the significance of a given station in the signalling system, in addition they may be densified with one or two times. As a result, the water level may be observed maximally on standard times at $6.00,12.00$, 18.00 and 24.00 UCT. The extraordinary observations are done in case of floods formations. The purpose of such observations is to catch the dynamics of the water level changes in the observed cross-section and if the station is classified as the signalling one the data on water level is used in the operating mode for the hydrological forecasts and the data participates in the warning system procedures. Water level reading times are subject to be densified and they are done every 3 , 2 and even every 1 hour, including the night hours. This data is the fundamental source of information while developing the hydrographs of theoretical floods. Based on the recorded water levels, the water flow value is read from the flow curve. The flow hydrograph course is made while using the linear interpolation between the particular flow values.

The continuous observations consist in recording the water level changes in time in a graphical way, a device known as limnigraph is used for that purpose. The final result of such observations is the mean daily level. The flow value is established based on the determined mean level and the current flow curve. In Figure 1 there is presented the general idea of data development from the continuous observations. The mean daily level is determined from the period from 0.00 to $24.00 \mathrm{UCT}$. Taking it into consideration, the flood course, according to the foregoing rule, should be interpreted as the level or flow histogram, which is shown in Figure 2.

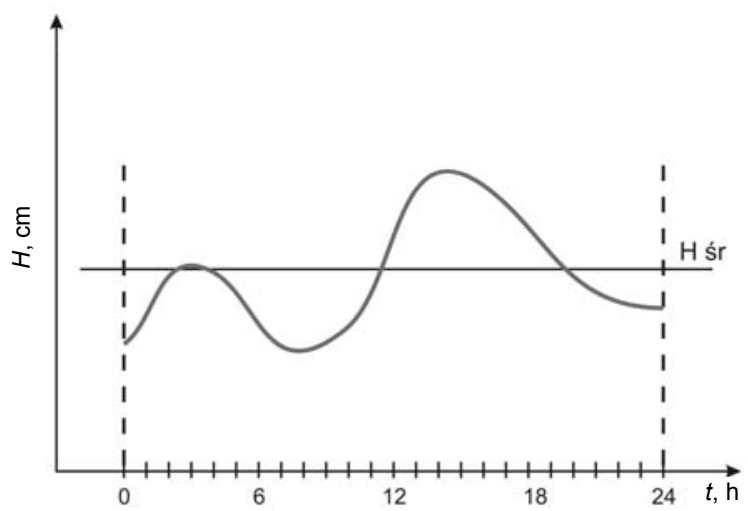

Fig. 1. Mean daily level for the data from the continuously recording system (limnigraph); source: own study

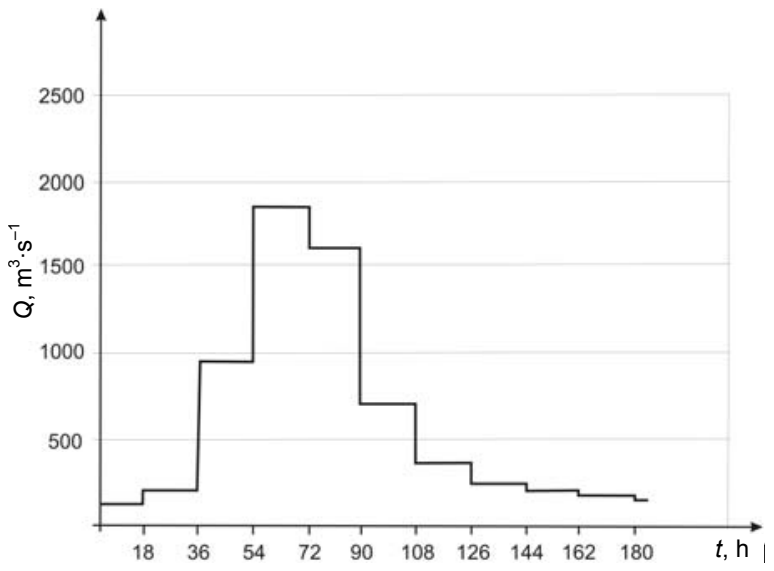

Fig. 2. Flow hydrograph (presented as histogram) for the data from the limnigraph system; source: own study

In addition, to this type of data it is attached the information on the level height or flow height at peak (i.e. flow maximum value) and the time of its occurrence. One should remember, however, that the peak water level has been previously considered while determining the mean daily level, therefore the peak value should be treated only as the information and not as a piece of data (Fig. 3).

A number of times, one may find, while developing the data, that the data from limnigraph system is treated as the periodical data (i.e. determined based on the staff-gauge), and it is an obvious mistake. If there is a necessity to have the graphical form of the limnigraph data presented in the form of traditional hydrograph, the particular flow values should be assigned to the hour 12.00 UCT and not as in the record of the historical database IMGW PIB to 6.00 UCT. In the Figure 4, the correct presentation form of this type of data is shown in the traditional layout of the flow hydrograph. One should remember that in such flow hydrograph, the peak flow, read from the extraordinary time of observation, is not considered and the volume of such flood is always smaller than the volume calculated for the flow hydrograph presented in 


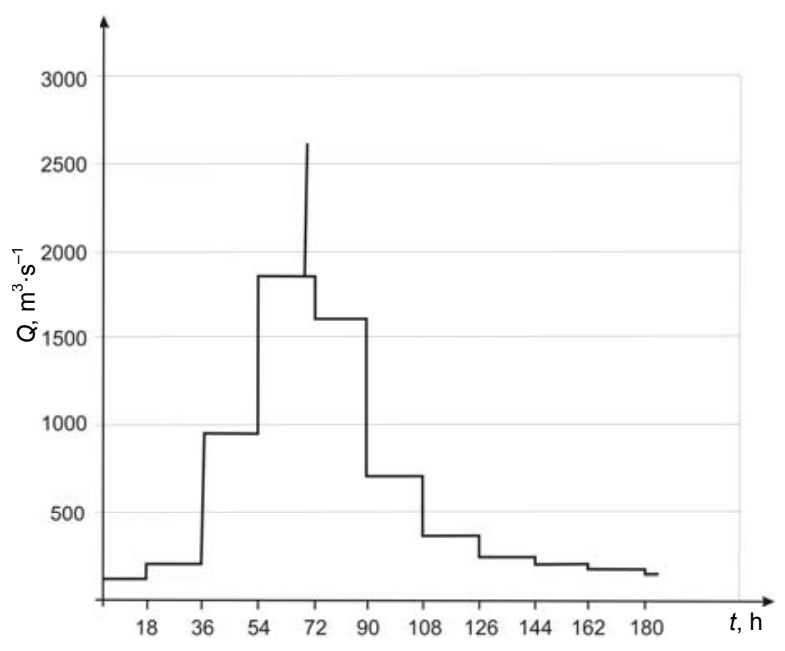

Fig. 3. Flow hydrograph with reference to the information on peak flow and its time of occurrence for the data from the limnigraph system; source: own study

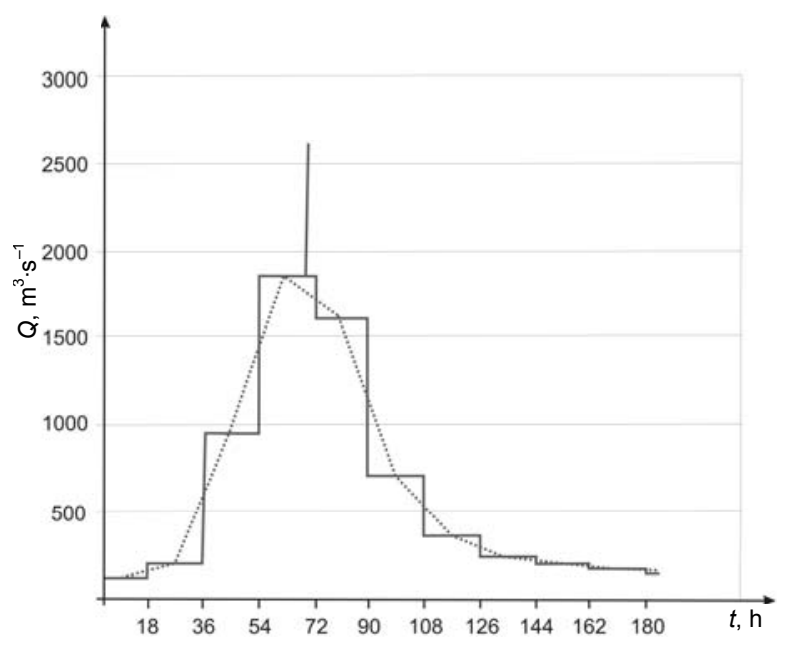

Fig. 4. Flow hydrograph presented in the traditional graphical layout (dashed line); source: own study

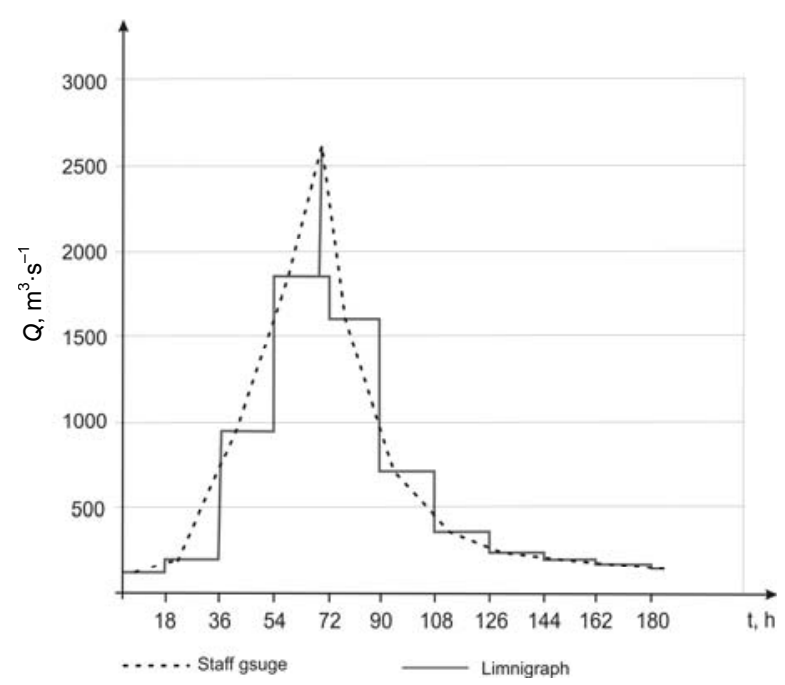

Fig. 5. Wrong presentation of flow hydrograph for data from the limnigraph system (dashed line); source: own study the form of histogram. This type of hydrograph is used for the assessment of the rising and declining curve behaviour for the flood data.

In most cases, the data recorded in the limnigraph system is shown in the graphical layout as in the Figure 5 , i.e. with reference to the flow peak values and the particular values are assigned to the hour 6.00 UCT. These are the rules which are applied while presenting the data recorded in the water-gauge system. Hence, in such approach to the graphical data presentation we have the combination of two completely different principles: traditional flow hydrograph with the flow mean values. From the formal point of view it is a mistake which leads to distort the course during the runoff process from the river catchment and to raise the flood volume in relation to the flow presentation in the flow histogram layout.

\section{ANALYSIS OF LIMNIGRAPH DATA USED FOR COMPARISONS}

For the influence assessment of the flow hydrograph for the limnigraph data treated for water-gauge data purposes, 8 water-gauge cross-sections were selected. For these cross-sections the data from both water-gauge and limnigraph systems was available. To assess the data usefulness for conducting the implied analyses, the verification has been carried out concerning the conformity of the limnigraph data record as the flow values determined from the water mean level. It is also necessary to remember about one more rule i.e. the limnigraph data refers to the whole hydrological year, in case of the device failure (limnigraph) or any other reasons disenabling to average the water levels, the flow value determined on the water level from 6.00 UTC is entered to the historical database IMGW PIB. Therefore, having at disposal the limnigraph data for a given flood, there are four possible types of data presentation:

a) all data is recorded in the limnigraph system,

b) rising part is recorded in the limnigraph system and declining part in the traditional water-gauge (mixed data of A type),

c) rising part is recorded in the water-gauge system and declining part in the limnigraph (mixed data of B type),

d) all data is recorded in the water-gauge system.

Unfortunately, that knowledge is obtained when both data systems are available. It is pity that in the coding system in the historical base there is no information what type of data the particular value represents. In the Table 1, there are presented the results of conducted analyses as for the information which the particular data sets showed.

As it was mentioned, 8 water-gauge sections were used for the analyses at which disposal there was the data recorded in the water-gauge and limnigraph systems. Those are the water-gauges in:

- Osielec on the Skawa river,

- Koniówka on the Dunajec river, 
Table 1. Flow values recorded in the limnigraph system with reference to the water-gauge data

\begin{tabular}{|l|c|c|c|c|}
\hline \multirow{2}{*}{$\begin{array}{c}\text { Water- } \\
\text {-gauge/ } \\
\text { river }\end{array}$} & $\begin{array}{c}|c| \\
\text { Number of floods according to the data record system } \\
\text { recorded in } \\
\text { the } \\
\text { limnigraph } \\
\text { system }\end{array}$ & $\begin{array}{c}\text { limnigraph } \\
\text { data in } \\
\text { flood rising } \\
\text { part }\end{array}$ & $\begin{array}{c}\text { limnigraph } \\
\text { data in } \\
\text { flood } \\
\text { declining } \\
\text { part }\end{array}$ & $\begin{array}{c}\text { data } \\
\text { recorded in } \\
\text { the water- } \\
\text {-gauge } \\
\text { system }\end{array}$ \\
\hline $\begin{array}{l}\text { Osielec/ } \\
\text { Skawa }\end{array}$ & $\mathbf{4}$ & $\mathbf{1}$ & 0 & $\mathbf{3}$ \\
\hline $\begin{array}{l}\text { Koniówka/ } \\
\text { Dunajec }\end{array}$ & $\mathbf{6}$ & 0 & 0 & $\mathbf{2}$ \\
\hline $\begin{array}{l}\text { Nowy Sącz/ } \\
\text { Dunajec }\end{array}$ & $\mathbf{8}$ & 0 & 0 & 0 \\
\hline $\begin{array}{l}\text { Żabno/ } \\
\text { Dunajec }\end{array}$ & $\mathbf{1}$ & 0 & 0 & $\mathbf{7}$ \\
\hline $\begin{array}{l}\text { Stary Sącz/ } \\
\text { Poprad }\end{array}$ & $\mathbf{2}$ & 0 & 0 & $\mathbf{6}$ \\
\hline $\begin{array}{l}\text { Nowy Sacz/ } \\
\text { Kamienica }\end{array}$ & $\mathbf{8}$ & 0 & 0 & 0 \\
\hline $\begin{array}{l}\text { Koszyce } \\
\text { Wielkie/ } \\
\text { Biała }\end{array}$ & $\mathbf{7}$ & $\mathbf{1}$ & 0 & 0 \\
\hline $\begin{array}{l}\text { Szczucin/ } \\
\text { Vistula }\end{array}$ & $\mathbf{6}$ & 0 & 0 & $\mathbf{2}$ \\
\hline
\end{tabular}

Source: own study.

- Nowy Sącz on the Dunajec river,

- Żabno on the Dunajec river,

- Stary Sącz on the Poprad river (Dunajec tributary),

- Nowy Sącz on the Kamienica river (Dunajec tributary),

- Koszyce Wielkie on the Biała river (Dunajec tributary),

- Szczucin on the Vistula river.

In consideration of the fact that in the water-gauge cross-section Żabno there was recorded only one flood in the limnigraph system, this cross-section was omitted in the further calculation part. The calculations apply the Cracow method for determination of the hypothetical floods course. In this method the calculations use 8 biggest floods. In the available data, there was no mixed data of B type i.e. water-gauge data for rising part and limnigraph data for declining part. The mixed data of A type (limnigraph data for rising part and water-gauge data for declining one) occurred on the water-gauge: Osielec on the Skawa river and in Koszyce Wielkie on the Biała river.

\section{THE CRACOW METHOD IN NUTSHELL}

The Cracow method was developed in the Hydrology Department of the Institute of Water Engineering and Water Management, Cracow University of Technology in 2010. The method was presented for the first time at $1^{\text {st }}$ Congress of Polish Hydrologists and the method description was included in the publications [GĄDEK 2010; 2012a]. Cracow Method was initially known as Cracow Technical University Method.

This method requires to have in a given water-gauge cross-section at least 8 large mono-modal floods recorded. The following assumptions are made: - as the floods there are understood the flows which are bigger than the limit flow determined based on the initial flow $Q_{0}$. As the initial flow $Q_{0}$ there is understood the flow with the elevation probability $Q_{p=50 \%}$;

- particular flood hydrographs are standardised to universal unit hydrograph for which there are established: rising time $t_{k}(\mathrm{~h})$, declining time $t_{o}(\mathrm{~h})$ and flood duration time $t_{b}$ (h) (basic time) being the total sum of rising and declining times $t_{b}=t_{k}+t_{o}$. The rising time is standardised irrespective of the declining time under $0-1$ system.

In addition there are determined:

- linear correlation for the duration time of the flood $t_{b}$ from the rising time $t_{k}, t_{b}=f\left(t_{k}\right)$ (Fig. 6A);

- linear correlation of the flood reduced volume from the reduced peak flow $V_{\text {zred }}=f\left(Q_{\text {zred }}\right)=f\left(Q_{\max }\right.$ $\left.Q_{p=50 \%}\right)$. The flood reduced volume means the wave volume above the limit flow $Q_{0}=Q_{p}=50 \%$ (Fig 6B).

Determination of the final hypothetical flood course is done based on:

a) development of the unified course of the single flood $U H J$, determination as the mean one from the unified single hydrographs $U H J_{i}$, (where $i$ is subsequent number of the flood used in the calculations);
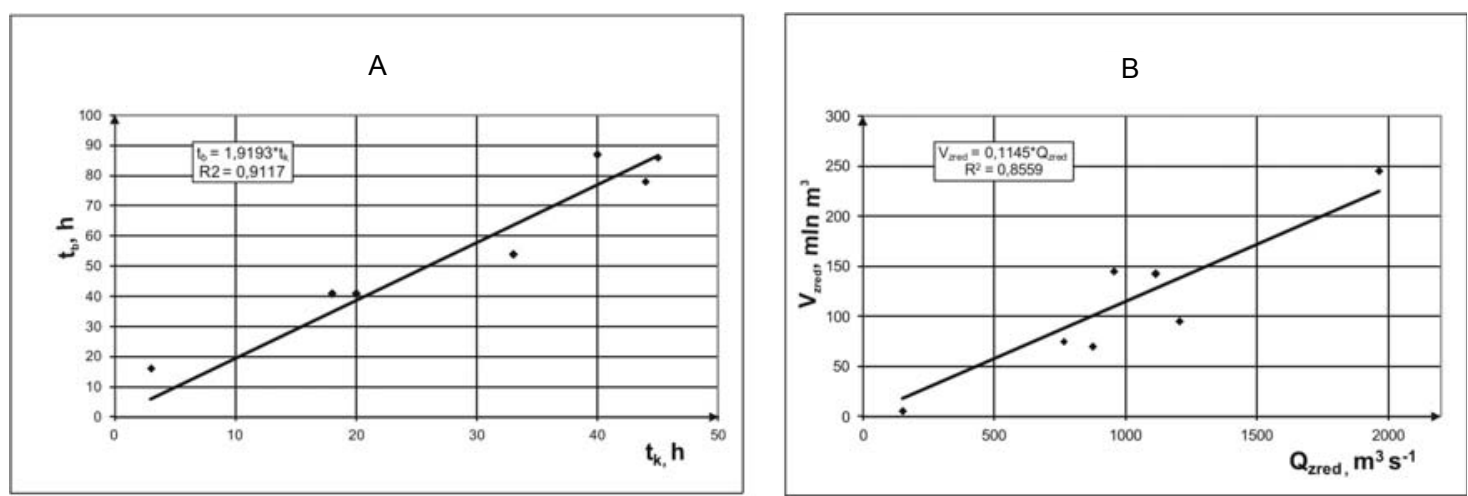

Fig. 6. Correlation of the basic time $t_{b}$ from the rising time $t_{k}$ for the floods included in the calculations (A) and the reduced volume $V_{\text {zred }}$ from the reduced flow $Q_{\text {zred }}(\mathrm{B})$; source: own study 
b) determination of the linear correlation for the flood duration time $t_{b}$ from the rising time $t_{k}, t_{b}=f\left(t_{k}\right)$ (Fig. 6A),

c) determination of the correlation of the flood reduced volume from the reduced peak flow $V_{\text {zred }}=$ $f\left(Q_{\text {zred }}\right)=f\left(Q_{\max }-Q_{p=50 \%}\right)($ Fig. 6B).

The final shape and course of the flood are established based on the reduced volume determined from the correlation $6 \mathrm{~B}$ for set peak flow, optimised rising time $t_{k}$ (time $t_{b}=f\left(t_{k}\right)$ ) and determined the measuring unified hydrograph $U H J$ for a given cross-section. The aim function in the assumed optimisation is the minimum difference between the set volume $V_{\text {zred }}=$ $f\left(Q_{\max }-Q_{p=50 \%}\right)$ and the searched volume for the set value of the rising time $t_{k}$.

\section{OBTAINED RESULTS}

During the conducted analysis, there was done the comparison of the hypothetical floods determined while using the data recorded in the limnigraph system with the hypothetical flood obtained for the water-gauge data. In the next Figures from 7 to 13 there are presented the graphical courses of the determined hypothetical floods for the data recorded in both the limnigraph and water-gauge systems. Each time the flood determined on the data from the water-gauge record is presented with solid line whereas the flood developed on the limnigraph data is marked with the dashed line.

In the next three tables there are presented the numerical values of the individual parameters describing the determined hypothetical floods for both systems of the data record. In the Table 2 there are compared the values of total reduced volume and the reduced volume for the rising part and the declining part of the hypothetical flood. This statement refers to the hypothetical flood determined both for the limnigraph data and for the flows from the staff-gauge data.

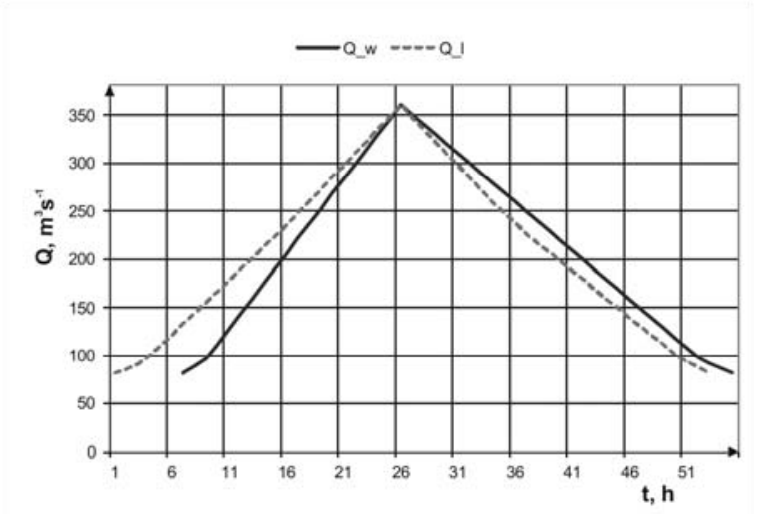

Fig. 7. Hypothetical hydrograph at the Osielec water-gauge cross-section on the Skawa River for $Q_{p=1 \%}$ developed by the Cracow method based on the limnigraph data (Q_1 hydrograph) and the staff-gauge data (Q_w hydrograph); source: own study

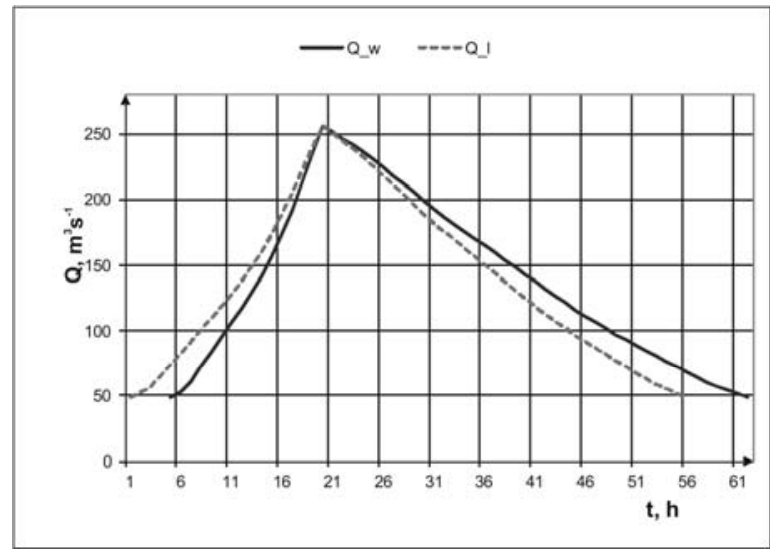

Fig. 8. Hypothetical hydrograph at the Koniówka water-gauge cross-section on the Dunajec River for $Q_{p=1 \%}$ developed by the Cracow method based on the limnigraph

data (Q_1 hydrograph) and the staff-gauge data (Q_w hydrograph); source: own study

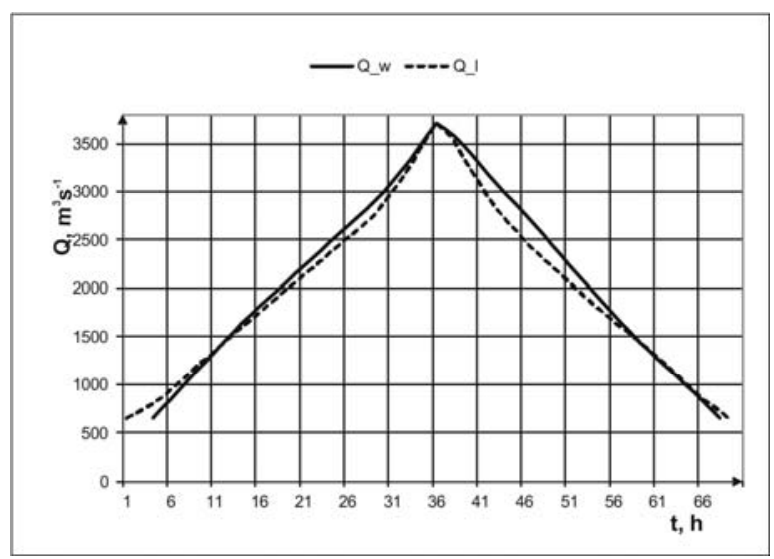

Fig. 9. Hypothetical hydrograph at the Nowy Sacz water-gauge cross-section on the Dunajec River for $Q_{p=1 \%}$ developed by the Cracow method based on the limnigraph data (Q_1 hydrograph) and the staff-gauge data (Q_w hydrograph); source: own study

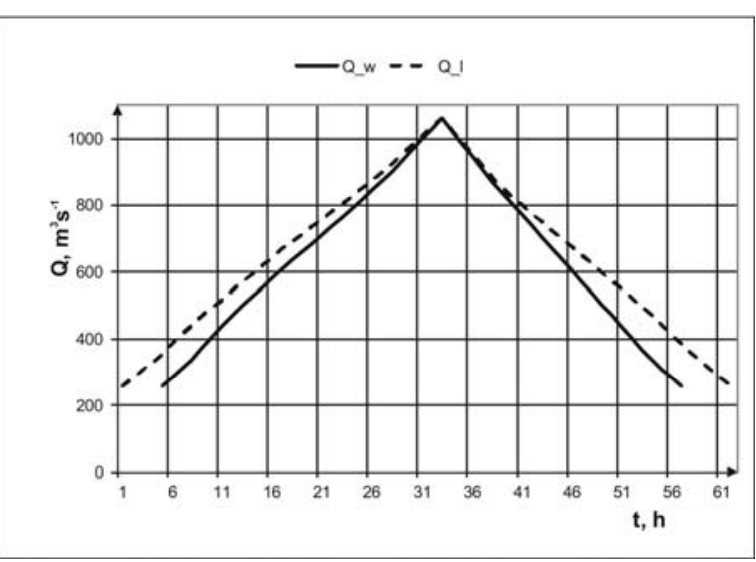

Fig. 10. Hypothetical hydrograph at the Stary Sącz water-gauge cross-section on the Poprad River for $Q_{p=1 \%}$ developed by the Cracow method based on the limnigraph

data (Q_1 hydrograph) and the staff-gauge data (Q_w hydrograph); source: own study 


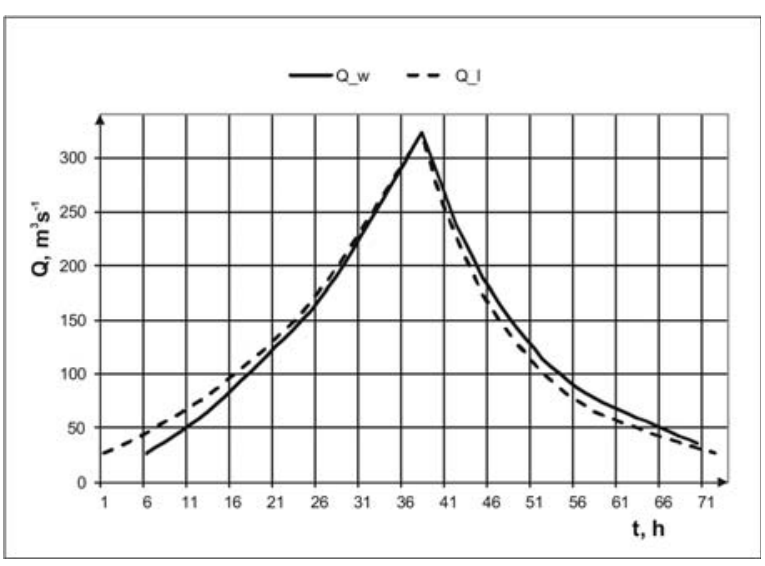

Fig. 11. Hypothetical hydrograph at the Nowy Sacz water-gauge cross-section on the Kamienica River for $Q_{p=1 \%}$ developed by the Cracow method based on the limnigraph data (Q_1 hydrograph) and the staff-gauge data (Q_w hydrograph); source: own study

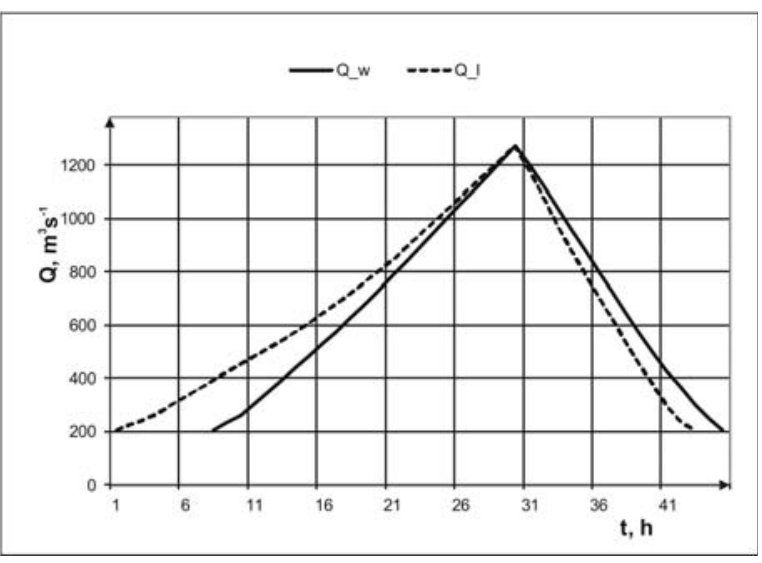

Fig. 12. Hypothetical hydrograph at the Koszyce Wielkie water-gauge cross-section on the Biała River for $Q_{p=1 \%}$ developed by the Cracow method based on the limnigraph data (Q_1 hydrograph) and the staff-gauge data (Q_w hydrograph); source: own study

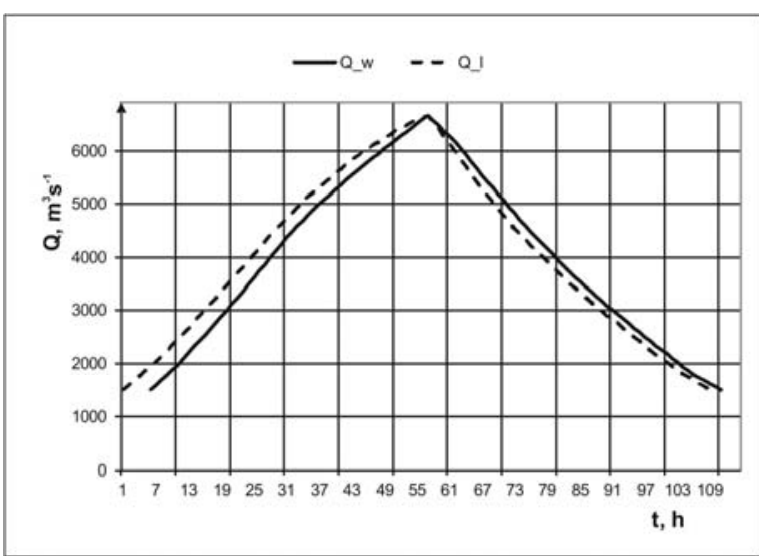

Fig. 13. Hypothetical hydrograph at the Szczucin water-gauge cross-section on the Vistula River for $Q_{p=1 \%}$ developed by the Cracow method based on the limnigraph data (Q_1 hydrograph) and the staff-gauge data (Q_w hydrograph); source: own study
Table 2. Reduced volume values for the hypothetical floods determined by the Cracow method based on the data recorded in the limnigraph data system and for the data recorded in the staff-gauge system

\begin{tabular}{|c|c|c|c|c|c|c|}
\hline \multirow[b]{3}{*}{$\begin{array}{l}\text { Water- } \\
\text {-gauge/ } \\
\text { river }\end{array}$} & \multicolumn{6}{|c|}{ Reduced volume, $10^{6} \mathrm{~m}^{3}$} \\
\hline & \multicolumn{3}{|c|}{ limnigraph data } & \multicolumn{3}{|c|}{ water-gauge data } \\
\hline & 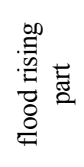 & 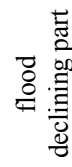 & 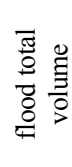 & 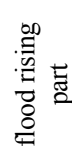 & 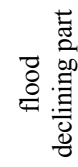 & 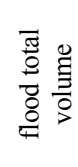 \\
\hline $\begin{array}{c}\text { Osielec/ } \\
\text { Skawa }\end{array}$ & 9.1 & 13.9 & 23.0 & 11.6 & 12.3 & 23.9 \\
\hline $\begin{array}{c}\text { Koniówka/ } \\
\text { Dunajec }\end{array}$ & 4.5 & 14.3 & 18.8 & 5.7 & 12.2 & 18.0 \\
\hline $\begin{array}{c}\text { Nowy } \\
\text { Sącz/ } \\
\text { Dunajec }\end{array}$ & 172.0 & 175.0 & 346.0 & 167.0 & 162.0 & 330.0 \\
\hline $\begin{array}{c}\text { Stary Sącz/ } \\
\text { Poprad }\end{array}$ & 40.1 & 33.1 & 73.2 & 46.3 & 39.8 & 86.1 \\
\hline $\begin{array}{c}\text { Nowy } \\
\text { Sącz/ } \\
\text { Kamienica }\end{array}$ & 13.9 & 11.6 & 25.5 & 15.2 & 10.2 & 25.4 \\
\hline $\begin{array}{c}\text { Koszyce } \\
\text { Wielkie/ } \\
\text { Biała } \\
\end{array}$ & 39.0 & 26.8 & 65,8 & 48.3 & 22.3 & 70.6 \\
\hline $\begin{array}{c}\text { Szczucin/ } \\
\text { Vistula }\end{array}$ & 503.0 & 448.0 & 951.0 & 570.0 & 412.0 & 982.0 \\
\hline
\end{tabular}

Source: own study.

Whereas, in the Table 3 there is given for the analysis the relative difference in volume in relation to the values developed for the hypothetical flood determined for the data from the water-gauge system:

$$
\Delta V=\frac{V_{L m}-V_{E_{w}}}{V_{\varepsilon_{w}}} 100 \%
$$

Table 3. Relative difference values of the reduced volume calculated according to the correlations (eq. 1) for the hypothetical floods determined by the Cracow method while using the data recorded in the limnigraph system in relation to the hypothetical flood determined for the data recorded in the staff-gauge system

\begin{tabular}{|c|c|c|c|}
\hline \multirow{2}{*}{$\begin{array}{c}\text { Water-gauge/ } \\
\text { river }\end{array}$} & \multicolumn{3}{|c|}{ Relative difference, \% } \\
\cline { 2 - 4 } & $\begin{array}{c}\text { flood rising } \\
\text { part }\end{array}$ & $\begin{array}{c}\text { flood } \\
\text { declining part }\end{array}$ & $\begin{array}{c}\text { flood total } \\
\text { volume }\end{array}$ \\
\hline $\begin{array}{c}\text { Osielec/ } \\
\text { Skawa }\end{array}$ & 27.6 & -11.8 & 3.7 \\
\hline $\begin{array}{c}\text { Koniówka/ } \\
\text { Dunajec }\end{array}$ & 26.8 & -14.3 & 4.4 \\
\hline $\begin{array}{c}\text { Nowy Sąc/ } \\
\text { Dunajec }\end{array}$ & -2.3 & -7.1 & -4.7 \\
\hline $\begin{array}{c}\text { Stary Sącz/ } \\
\text { Poprad }\end{array}$ & 15.3 & 20.2 & 17.5 \\
\hline $\begin{array}{c}\text { Nowy Sącz/ } \\
\text { Kamienica }\end{array}$ & 9.2 & -11.8 & -0.4 \\
\hline $\begin{array}{c}\text { Koszyce Wielkie/ } \\
\text { Biała }\end{array}$ & 23.9 & -16.8 & 7.3 \\
\hline $\begin{array}{c}\text { Szczucin/ } \\
\text { Vistula }\end{array}$ & 13.3 & -8.0 & 3.3 \\
\hline
\end{tabular}

Source: own study. 
where:

$\Delta V$ relative difference in volume with reference to the hypothetical flood determined with the Cracow method for the data from the water-gauge system, \%;

$V_{\text {Lim }}$ hypothetical flood volume calculated for the flood developed for the limnigraph data, $10^{6}$ $\mathrm{m}^{3}$;

$V_{E . w}$ hypothetical flood volume calculated for the flood developed for the water-gauge data, $10^{6} \mathrm{~m}^{3}$.

The last Table 4 shows the rising, declining and basic time values for both types of the hypothetical floods (water-gauge and limnigraph).

Table 4. Rising, declining and basic time values for the hypothetical floods determined by the Cracow method while using the data recorded in the limnigraph system and for the flows determined based on the data recorded in the staff-gauge system

\begin{tabular}{|c|c|c|c|c|c|c|}
\hline \multirow[b]{3}{*}{$\begin{array}{l}\text { Water- } \\
\text {-gauge/ } \\
\text { river }\end{array}$} & \multicolumn{6}{|c|}{ Time, $\mathrm{h}$} \\
\hline & \multicolumn{3}{|c|}{ limnigraph data } & \multicolumn{3}{|c|}{ water-gauge data } \\
\hline & 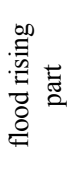 & 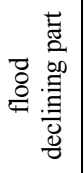 & 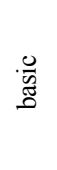 & 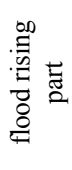 & 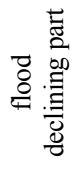 & . \\
\hline $\begin{array}{l}\text { Osielec/ } \\
\text { Skawa }\end{array}$ & 25 & 27 & 52 & 19 & 29 & 48 \\
\hline $\begin{array}{l}\text { Koniówka/ } \\
\text { Dunajec }\end{array}$ & 19 & 36 & 55 & 15 & 42 & 57 \\
\hline $\begin{array}{c}\text { Nowy Sącz/ } \\
\text { Dunajec }\end{array}$ & 35 & 33 & 68 & 32 & 32 & 64 \\
\hline $\begin{array}{c}\text { Stary Sacz / } \\
\text { Poprad } \\
\end{array}$ & 32 & 29 & 61 & 28 & 24 & 52 \\
\hline $\begin{array}{c}\text { Nowy Sącz/ } \\
\text { Kamienica }\end{array}$ & 39 & 34 & 73 & 32 & 35 & 67 \\
\hline $\begin{array}{c}\text { Koszyce } \\
\text { Wielkie/ Biała }\end{array}$ & 29 & 13 & 42 & 22 & & 37 \\
\hline $\begin{array}{l}\text { Szczucin/ } \\
\text { Vistula }\end{array}$ & 56 & 52 & 108 & 51 & 54 & 105 \\
\hline
\end{tabular}

Source: own study.

\section{SUMMARY}

While approaching the assessment of the influence of the data from limnigraph system on the final course of the hypothetical floods, it was presumed that the difference in relation to the hydrograph determined on the flows established on the data read from the staff-gauge would be significant. However, it is not so; the differences, that can be observed, refer to the rising time, where the time for every watergauge cross-section is bigger while using the limnigraph data. Whereas, the declining time is shorter in general. It is also noticeable that shift in the rising time for the limnigraph data amounts ca. 6 hours, which means that in case of having the information that the data for a specific flood is recorded in the limnigraph system, it is possible to assign the particular hydrograph input values to the hour 12.00 and you will automatically obtain the correction of the hydrograph course by the value of the occurring error. However, there is no such information, i.e. such correction cannot be done.

Significantly bigger problem happens in case of the hypothetical flood volume. Based on the obtained results, it is possible to draw a conclusion that in case of the similar group of floods recorded in the limnigraph system there are small differences in the floods volume in relation to the hydrographs determined on the flows from the staff-gauge. At 7 analyzed watergauge cross-sections, it is a too long-range conclusion. What can be noticed is that the volume in the rising part is bigger, whereas in the declining part it is smaller in relation to the flood determined for the data from the water-gauge system. The mistake being made in the volume estimation of the hypothetical floods, while using the limnigraph data, is small enough to expect that the hypothetical hydrographs developed on the limnigraph data would not disturb significantly the actions connected with usage of this type of data in the design works or expert opinions.

One can assume that the Cracow method, by making allowance in the calculation procedure for the correlations of the basic time and rising time as well as the flood volume from the maximum flow at peak, reduces the disturbances caused by other data presentation method on the flow in the river-bed.

\section{REFERENCES}

Apel H., Thieken A.H., Merz B., Blöschl G. 2006. A probabilistic modelling system for assessing flood risks. Natural Hazards. Vol. 38 p. 295-308.

BAPTISTA M., Michel C. 1990. Influence des characteristiques hydrauliques des bies sur la propagation des pointes de crue. La Houille Blanche. No 2 p. 141-148.

Boughton W., Droop O. 2003. Continuous simulation for design flood estimation - a review. Environmental Modelling and Software. Vol. 18 p. 309-318.

Büchele B., Kreibich H., Kron A., Thieken A., Ihringer J., Oberle P., Merz B., Nestmann F. 2006. Flood-risk mapping: contributions towards an enhanced assessment of extreme events and associated risks. Natural Hazards and Earth System Sciences. Vol. 6 p. 485-503.

ByCzKOwSKi A. 1996. Hydrologia [Hydrology]. T. 1. Warszawa. SGGW. ISBN 83-00-02925 pp. 375.

CBSiPWM 1971. Przykłady obliczeń hydrologicznych do opracowań wodno-melioracyjnych [Hydrological calculations for land reclamation studies: examples]. Warszawa. Praca studialna. Nr 126.

CiePielowsKi A., DĄBKowsKi Sz.L. 2006. Metody obliczeń przepływów maksymalnych w małych zlewniach rzecznych [Methods for calculating maximum discharges in small catchments]. Bydgoszcz. Ofic. Wydaw. Projprzem - EKO. ISBN 978-83-922194-1-5 pp. 311.

ERnst J., Dewals B.J, Detrembleur S., Archambeau P. 2010. Micro-scale flood risk analysis based on detailed 2D hydraulic modelling and high resolution geographic data Natural hazards. Natural Hazards. Vol. 55 p. 181209.

GĄDEK W. 2010. Fale hipotetyczne o zadanym prawdopodobieństwie przepływu w kulminacji. Hydrologia w inżynierii i gospodarce wodnej [Hypothetical flood 
wave with fixed peak value exceedance probability]. T. 1. Warszawa. Komitet Inżynierii Środowiska PAN. Monografia. Nr 68 p. 177-186.

GĄDEK W. 2012a. Wyznaczanie wezbrań hipotetycznych metodą Politechniki Warszawskiej i metodą Politechniki Krakowskiej w zlewniach kontrolowanych. Cz. 1. Opis metod [Determination of theoretical swells in gauged catchments using Warsaw University of Technology method and Cracow University of Technology method. Part 1. Method's description]. Czasopismo Techniczne. Z. Ś-2. p. 95-104.

GĄDEK W. 2012b. Wyznaczanie wezbrań hipotetycznych metodą Politechniki Warszawskiej i metodą Politechniki Krakowskiej w zlewniach kontrolowanych. Cz. 2. Ocena metod [Determination of theoretical swells in gauged catchments using Warsaw University of Technology method and Cracow University of Technology method. Part 2. Method's evaluation]. Czasopismo Techniczne. Z. Ś-2. p. 105-126.

JONKMAN S.N., VRIJLING J.K., VROUWENVELDER A.C.W.M. 2008. Methods for the estimation of loss of life due to floods: a literature review and a proposal for a new method. Natural Hazards. Vol. 46 p. 353-358

KICIŃSKI T. 1965. Konstrukcja fali wezbraniowej prawdopodobnej [Construction of probable flood hydrograph]. Zeszyty Naukowe SGGW. Melioracje Rolne. Nr 6 p. 49-71.
Linsley Jr. R.K., Kohler M.A., PAulhus J.L.H. 1975. Hydrology for engineers. Monograph. New York. McGrawHill, Incorporated. ISBN 00135026 pp. 482.

MCENROE B.M. 1992. Sizing stormwater detention reservoirs to reduce peak flows. In: Hydraulic engineering: saving a threatened resource - in search of solutions. Conference Proceeding Paper. Reston, VA. ASCE p. 719-724.

PILGRIM D. 2001. Australian rainfall and runoff. A guide to flood estimation. Monograph. Vol. 1. ISBN 0-85825-7440 .

Sarma P.B.S., Delleur J.W., RaO A.R. 1973. Comparison of rainfall - runoff models for urban areas. Journal of Hydrology. Vol. 18 p. 329-347.

STRUPCZEWSKI W. 1964. Równanie fali powodziowej [Equation for flood hydrograph]. Wiadomości Służby Hydrologicznej i Meteorologicznej. Nr 2(57).

VRIJLING J.K., VAN HeNGel W., Houben R.J. 1998. Acceptable risk as a basis for design. Reliability Engineering and System Saferty. Vol. 59 p. 141-150.

WAŁĘGA A. 2013. Application of HEC-HMS programme for the reconstruction of a flood event in an uncontrolled basin. Journal of Water and Land Development. No $18 \mathrm{p}$. 13-20.

WANG W., VAN Gelder P.H.A.J.M., VRIJLING J.K., MA J. 2006. Forecasting daily streamflow using hybrid ANN models. Journal of Hydrology. Vol. 324 p. 383-399.

\section{Wiesław GĄDEK}

\section{Ocena przydatności danych limnigraficznych do wyznaczania fal hipotetycznych metodą krakowską}

\section{STRESZCZENIE}

\section{Slowa kluczowe: dane limnigraficzne, dane wodowskazowe, metoda krakowska, wezbranie hipotetyczne}

Dane dotyczące objętości przepływu w ciekach są w Polsce rejestrowane w trzech systemach bazodanowych: wodowskazowym, limnigraficznym i telemetrycznym (cyfrowym). W każdym z tych systemów wartość objętości przepływu prezentowana jest w odmienny sposób. Najbardziej korzystny jest system telemetryczny, ale działa on dopiero od 10 lat. Najwięcej danych zostało zebranych w systemie limnigraficznym. W systemie tym dane o przepływach reprezentują wartość średniego przepływu dobowego, natomiast dane rejestrowane w systemie wodowskazowym podają wartości chwilowe odczytane w terminach obserwacyjnych. W obu tych systemach hydrogram przepływu jest uzupełniany informacją o wartości i czasie wystąpienia przepływu maksymalnego. Celem publikacji jest przedstawienie wpływu nieprzestrzegania odmienności znaczeniowej i merytorycznej danych wodowskazowych i danych limnigraficznych na przykładzie siedmiu wezbrań hipotetycznych wyznaczonych metodą krakowską. Uzyskane wyniki wskazują, że dane o hydrogramie przepływu pochodzące z systemu zapisu limnigraficznego nie wpływają w sposób zasadniczy na parametry wezbrań hipotetycznych. $Z$ powodu braku danych z systemu telemetrycznego zapisu danych takiej analizy nie dokonano. 